\title{
A hallássérült kisgyermekek életútját meghatározó korai szürés, hallókészülék-illesztés és a korai fejlesztés jelentősége
}

\author{
Baranyi Ildikó \\ ELTE Bárczi Gusztáv Gyógypedagógiai Kar, speciális pedagógiaszakos tanár és szakpedagógus \\ SOTE Fül-Orr-Gégészeti és Fej-Nyaksebészeti Klinika, gyógypedagógus
}

\begin{abstract}
Hazánkban a hallássérült kisgyerekek korai fejlesztése a naturális-verbális-orális terápia elveit követi. Azok a családok, akik hallássérült kisgyerekük számára ezt az utat választják, a halló gyerekek természetes beszédfejlődését alapul véve a hangos beszéd elsajátítását tüzik ki célul.

Az első életévek történései kulcsfontosságú szerepet játszanak a későbbi életévek szempontjából. A korai szürés, diagnosztika, a hallókészülék kiválasztása és illesztése, a cochleáris implantáció szükségességének felismerése, az interdiszciplináris gondolkodás, mind alapkövei a sikeres korai fejlesztésnek, és az azt követő időszaknak. Jelen tanulmány a korai fejlesztéshez vezető út bemutatása mellett érinti a szülö-terapeuta együttmüködésének szempontjait is. Bemutatja a közeljövőben várható pozitív változásokat, ezzel együtt az ellátórendszer föbb nehézségeit is.
\end{abstract}

Kulcsszavak: hallássérülés következményei, teljes körü újszülöttkori szürés, diagnosztika és hallókészülék-illesztés, korai fejlesztés - korai intervenció, az ellátórendszer nehézségei

\section{Bevezetés}

Kommunikációra való igényünk, veleszületett emberi jellemzőink egyike. A születés pillanatától elkezdődik az a nagy, felfedező utazás, mely során a minket ért hatások révén tapasztalatokat szerzünk közvetlen környezetünkröl, és ezzel kezdetét veszi egy hosszú folyamat, az élethosszig tartó tanulás. Az első nagy lépés már az anyaméhben megkezdődik. Az érzékszervek már a 8. gesztációs héten alkalmasnak mutatkoznak arra, hogy kapcsolatba lépjenek az embrió a környezetével, a negyedik hónapban már a magzat egész teste érzékeny az érintésre. A 14. héttöl meg tud különböztetni illatokat, ízeket, fény felé fordul, és a 16 hetes magzat már érzékeli az anya testében lévő hangokat. A 24. hét körül kifejlődik a magzat belső füle, és innentől fogva képessé válik egyes hangok - így például az anya szívhangja - meghallására. A külvilágból érkező hangosabb hangokat is képes lesz érzékelni, elsősorban édesanyja és édesapja hangjára reagál, anyja beszédének hatására szívverése felgyorsul. Mindez a magzat és a külvilág közötti kapcsolat, a kommunikáció kezdetét is jelenti (Ranschburg, 2007).

A hangok tehát már a születés előtt többlettartalommal bírnak és túlnyúlnak a hallás önmagában való jelentőségén. A korai kötődés első állomása mellett, emocionális, kommunikációs tartalommal hidat képeznek az újszülött számára a születés előtti és a születés utáni időszak között.

\section{Az anya-gyerek kommunikáció alapjai, a természetes beszédfejlődés}

Az újszülött elsődleges kommunikációs eszköze a sírás, mely azonnali reakciót vált ki a környezet részéröl. Így tanulja meg, hogy a sírás az aktuális állapot kifejezése mellett üzenet is egyben, melyet a környezet megpróbál megérteni, orvosolni. Ez vezet el odáig, hogy sírása differenciálódik, és a kisbaba megtanulja, mikor hogyan sírjon. Két 
hónapos kora körül már máshogy sír, ha fájdalma van, másként, ha éhes, ha kellemetlensége van, vagy ha unatkozik.

Háromhónapos kor körül a csecsemő gazdagabb hangadásra képes, beszédszerve fejlődik. Vokalizálását, gőgicsélését az édesanya visszautánozza, érzelmekkel jutalmazza. A csecsemő újra reagál, mire az anya ismét válaszol, és ezzel megerősíti gyermeke kezdeményezését. Jelentést kapnak a hangok, az anyai reakció erősíti kettejük kommunikációját. Ebben a folyamatban nemcsak a hangok cserélődnek, és kapnak megerősítést, hanem az azokhoz kötődő arckifejezések is. Az arckifejezések is visszatükröződnek, egymásra hangolódnak. Ez az interakció, a beszélgetés alapja, a „most te, most én, most te, most én” ritmusa, az egymásra való figyelem, mely a szerepcsere, a későbbi beszélgetés lényege.

Az anya a kommunikációja során egy különleges „dajkanyelvvel” fordul a gyermeke felé, így üzenve meg számára a szeretetét.

A szeretetbeszéd jellemzői minden nyelvben jellegzetesek az anyai beszédben. Magasabb hangszín, dallamosabb beszéd, elnyújtott magánhangzók a szavakban, színes intonáció, rövidebb mondatok, sok ismétlés. A csecsemő-anya interakcióban kiemelt szerep jut még a tekintetnek. A kölcsönös figyelem a másikra, a szem, a hang és az érzelmek együttes találkozásával lesz teljes, és vezet el a preverbális időszakban a verbális kommunikáció alapjaihoz.

A kisgyerek nyelvi fejlődéséhez tehát nagymértékben hozzájárul a környezet, mely körülveszi őt. Az ismétlések révén egyre több mintája lesz, idővel a gyermeki gagyogás egyre inkább hasonlít a környezet hangjaihoz, megjelennek az utánzás jegyei, a halandzsa nyelv használata, az egyszavas kijelentések. Egy-másfél éves kor között az ép halló kisgyerek már aktívan használ néhány szót, és viszonylag fejlett a beszédértése. A folyamatos kommunikáció során szókincse gyors fejlődést mutat, a szótanulás üteme felgyorsul. A nyelvi robbanás, vagy „szórobbanás” időszaka átlagban másfél és kétéves korra tehető. Ebben az időszakban a szókincs látványos és gyors fejlődésnek indul, a szavak mondatokká formálódnak. Egy új szókapcsolat kerül a gyermekek szókincsébe. „mi az?”

3 éves kor körül az anyanyelv alapjait elsajátítja a gyermek, egy 5-6. életév végéig pedig az anyanyelv főbb szabályai is beépülnek a gyermek nyelvhasználatába.

A környezeti tényezők mellett, a normál nyelvfejlődés további kritériumai a hallás, az idegrendszer és a beszédszervek épsége és megfelelő müködése.

Bármelyik terület sérülése esetén a nyelvfejlődés lelassul. Kellő diagnózis és terápia hiányában idővel irreverzibilis folyamatok indulnak el mindezzel, akár végleges elmaradást okozva.

\section{Az első hallásélmények jelentősége, az anyanyelvre való ráhangolódás}

Az újszülött és csecsemőkori kutatások jelentős része fókuszba helyezi annak felderítését, hogy milyen előzetes tudással születnek az újszülöttek, és ez a tudás meddig tárolódik el emlékezetükben. Bizonyított, hogy a néhány órás ép hallású újszülöttek már nemcsak édesanyjuk hangját képesek megkülönböztetni a környezet más hangjaitól, hanem arra is képesek, hogy a saját anyanyelvi hangkészletüket felismerjék és elkülönítsék más nyelvek hangkészletétől. Univerzális hallásuk révén pedig 6-7 hónapos korban még képesek elkülöníteni az anyanyelv hangkészletében nem szereplö, de más nyelvben alig érzékelhető hangok közötti különbséget, 10 hónapos korukra azonban a hallásuk többé már nem univerzális, és ezt követően már nem hallják meg a két hang közötti különbséget (Werker, Jeung és Joshida, 2012). 


\section{A hallássérülés következményei}

De mi történik, ha az újszülött hallássérüléssel érkezik a világra és hiányoznak a hallási tapasztalatok?

Bár a hallási reakciók elmaradásának nyilvánvaló jelei vannak, észrevételük és értelmezésük gyakran mégsem egyértelmü a környezet számára. Az elmúlt több évtizedes hazai gyakorlat azt mutatja, hogy a halló családokba született hallássérült kisgyerekek diagnózisának időpontja messze elmarad az kívánatostól. Különösen érvényes lehet ez az első gyermek esetében. A szülőknek még nincs előzetes tapasztalata, nehezebben veszik észre azokat a gyanújeleket, amik egyértelmüsítenék a hallássérülést.

A szülök szempontjából nehezítheti a felismerést az is, hogy 5-6 hónapos korig a hangadás, a gőgicsélés és a gagyogás egy veleszületett, belső program alapján müködik, így a hallássérült gyerekeknél is megjelennek ezek a szakaszok. Habár néhány esetben az anyák visszaemlékezve már egyértelmüsítik a korai jeleket, azok mégsem voltak eléggé nyilvánvalóak ahhoz, hogy időben szakemberhez forduljanak. Sajnálatos, de az sem ritka, hogy pont maga a szakember altatja el a szülői gyanút, és ezzel egy újabb vizsgálatig jelentős időt veszít a kisgyerek. A korai gyanújelek annál egyértelműbben fellelhetők, minél súlyosabb a hallássérülés, és ennek következtében, minél inkább hiányoznak a hangokra adott válaszreakciók.

A hallási reakciók elmaradása vagy teljes hiánya gyakran csak akkor válik bizonyossá, ha nem indul meg, vagy jelentős késést mutat a nyelvfejlődés. A veleszületett súlyos fokú halláscsökkenés negatív hatással van a korai kommunikációs készségekre, amelyek döntő fontosságúak a nyelvi fejlődés szempontjából (Archbold, 2010).

A hallássérülés mértékétől függően nem, vagy csak jelentős elmaradással indul meg a beszédfejlődés. A kisgyerek bizonyos hangokat jobban, másokat kevésbé, vagy egyáltalán nem hall meg, így nehezítetté és aránytalanná válik egyes szavak meghallása. Ennek hosszú távú következményeként a szókincs szegényesebb, a beszéd pedig ritmustalanabb, monotonabb lesz.

Késői diagnózis esetén, másodlagos következményeként érintettek lehetnek a szociális, érzelmi fejlődés területei is. A hallássérült csecsemő és a halló anya közötti kommunikációból hiányoznak, vagy csak részben vannak jelen azok az üzenetek, melyeket az anya a szeretetbeszéd eszköztárán keresztül elsősorban emocionális síkon közvetít gyermeke felé. A nem megfelelő anya-gyerek kommunikáció, az anya-gyerek kapcsolatra is kihatással van, idővel pedig személyiségfejlődési, és szocializációs problémákat is eredményezhet.

Éppen ezért a korai diagnózis, a hallássérülés felfedezésén túl, prevenciós jelentőségű is, mivel sem az anya, sem a kisgyerek nem éli át a „nem megértettség” érzését, bizonytalanságát. A halló családok a hallássérülés tényének bizonyosságával választ kapnak olyan élethelyzetekre, kérdésekre is melyek ezelött bizonytalanságot okoztak és, melyek segítenek megismerni a gyermekük speciális szükségleteit, elindítva őket a korai fejlesztés felé.

\section{A korai fejlesztéshez vezető út}

A hallássérült kisgyerekek korai fejlesztéshez vezető út országos viszonylatban információk hiányában gyakran nehezített és időveszteséggel jár. A még érvényben lévő, többségében csak reakciókat néző szürés eredménye megbízhatatlan. A diagnosztika, audiológiai ellátás, hallókészülék kiválasztás, a szakértői javaslat szükségessége, 
a korai fejlesztés helyszínének kijelölése, majd a hallássérültek pedagógiája szakos terapeutával való kapcsolatfelvétel gyakran hosszú, fáradságos „kutatómunka” eredményeként jut csak el a szülőkhöz.

\section{Az újszülöttkori hallásszürés}

1993 óta Washingtonban, egy szülöi szervezet a JCIH (Joint Committee on Infant Hearing) kezdeményezésére, több országban is bevezették az UNHS-t (Univerzális Neonatális Hallásszűrést), mely módszer az újszülötteket objektív módon szűri. A szürésre épülő program következtében a szürővizsgálaton fennakadt újszülöttek egy újabb objektív kontrollmérésen vesznek részt. Ha annak az eredménye is igazolja a hallássérülést, további vizsgálatokat követően kezdetét veszi a hallássérülést feltérképező folyamatdiagnózis és a megfelelő hallókészülék kiválasztása, illesztése. A kiszűrt csecsemők 3-4 hónapos koruktól fogva a próbakészülékek segítségével hangélményhez jutnak, és fél éves korukra már a véglegesített hallókészülékkel megkezdődik a tanácsadás-irányítás, a terapeutával való közös munka. A JCHI adatai alapján, 1000 születésre 3 hallássérült kisbaba esik, ebben a súlyostól az enyhe fokú hallássérülésig minden maradandó hallássérülés beletartozik.

Egy másik kutatócsoport eredményei alapján 1000/ 2.6 az arány (Marschark, 2009), így átlag tekintetében érvényesnek tekinthető, hogy 1000 kisbabából megközelítőleg 3 születik hallássérültként.

\section{Az újszülöttkori hallásszűrés hazai helyzete}

Magyarországon az újszülöttek hallásszűrése 1983 óta teljes körü, de nem objektív. Az objektív módszer lényege, hogy nem szubjektív (a viselkedés változásán alapuló megfigyelés) módon történik annak megítélése, hogy van-e vagy nincs hallási reakciója az újszülötteknek, hanem műszeres vizsgálattal. A szubjektív vizsgálatok nem frekvenciaspecifikusak, megítélésük bizonytalan és pontatlan. Továbbá a megfigyelésen alapuló módszerrel nem szürhető ki sem a közepes, sem az enyhefokú, sem pedig az egyoldali hallássérülés.

Az utóbbi évtizedekben hazánkban is jelentős törekvések voltak arra, hogy külföldi minták alapján egységesen bevezetésre kerüljön az újszülöttek teljes körü objektív hallásszűrése. Az objektív hallásszűrést (BERA, ABR, OAE) Pécsett és Baján 1997-ben dr. Pytel József professzor és dr. Beke Zsolt vezették be először (Beke, 2009). E munkájukkal nemcsak hazánkban, hanem egész Közép-Európában élen jártak. Bár 2005-ben, 27 helyen, az újszülöttek 32\%-át vizsgálták meg teljes körű objektív módszerrel, sajnálatos, hogy az elmúlt években visszaesés történt, mely elsősorban a bezárt szürőállomások és a még mérést végző szűrőhelyek színvonalbéli romlása miatt következett be (Baranyi-Fejes, 2012).

Előrelépés volt, hogy az egészségügyben dolgozó szakemberek együttmüködése eredményeként, 2010-ben az Egészségügyi Minisztérium alá tartozó Országos Gyermekegészségügyi Intézet szakmai irányelvet fogalmazott meg a Fül-Orr-Gégészeti Szakmai Kollégium, a Csecsemő- és Gyermekgyógyászati Szakmai Kollégium, és a Védőnői Szakmai Kollégiummal egyeztetve. Az irányelv tartalmazza a 0-18 éves korig szükséges szürés életkorra bontott föbb állomásait, különös hangsúlyt fektetve a nyelvelsajátítás szempontjából kritikus időszak, valamint az újszülött- és csecsemőkori hallásvizsgálatok jelentőségére (Beke, 2009). Sajnos az irányelv törvényi szintre emelése évekig váratott magára. Azonban örömteli hír, hogy a közelmúltban a szakmai 
irányelvek újragondolása után az Emberi Erőforrás Minisztérium által a módosító beadvány elfogadásra talált, így előreláthatólag Magyarországon 2015 szeptemberétől az új törvényi szabályozás lép életbe. Ez alapján 2015. szeptember elsejétöl kezdve minden újszülöttet objektív módszerrel kell szürni a születését követő 0-4. nap között a szülészeti osztályon (Magyar Közlöny, 2015).

A közeljövőben bevezetésre kerülő UNHS-program új helyzet elé állítja a hallássérültek pedagógiája szakos gyógypedagógusokat is, ugyanis korábban csak nagyon kivételes esetben találkoztak egyéves kor alatti hallássérült kisgyerekekkel. A szürés következtében várhatóan már a pár hónapos csecsemők is hallókészüléket kaphatnak.

Az objektív hallásszürés kötelező jellegének bevezetése hosszútávon is döntő jelentőségű a veleszületett hallássérült kisgyerekek életútja szempontjából. A korai diagnózis esélyt adhat arra, hogy a korai hallókészülék-ellátással a csecsemő hozzájuthasson azokhoz a hangokhoz, környezetében lévő fontos információkhoz, amik nélkülözhetetlenek a preverbális kommunikáció és a nyelv fejlődése szempontjából.

\section{Diagnosztika}

\section{Audiológiai ellátás - hallókészülék ellátás}

A korrekt diagnosztika és az erre épülő hallókészülékes ellátás életkortól függetlenül megkívánja az objektív és szubjektív módszerek együttes alkalmazását, a kapott eredmények együttes mérlegelését, összevetését. Csecsemők és kisgyerekek esetében a hallókészülék-ellátás az alacsony életkor miatt különösen igényli a speciális szaktudást és széleskörü látásmódot. Az ellátást végző szakemberektől kívánalom, hogy az objektív (OAE, ABR, BERA, ASSR) vizsgálat eredményit az életkor specifikus (magatartás-megfigyelő audiometria 0-6. hó, vizuális megerősítő audiometria 6-30. hó, játékaudiometria 30. hónaptól) szubjektív vizsgálatok eredményeivel vessék öszsze, és emellett vegyék számításba a gyerekek életkorából adódó illesztés speciális szempontjait is (Keresztessy, 2012).

Az orvosi, audiológiai, akusztikai és gyógypedagógiai tudás összeadására és együttmüködésére nagy szükség lenne.

Amennyiben a vizsgálat eredménye indokolttá teszi a kisgyerek hallókészülékes ellátását, az audiológus orvos javaslata alapján a következő állomás a fülillesztékhez szükséges lenyomatvétel. 1-2 héttel később az elkészült illesztékkel elkezdődhet az első hallókészülék kipróbálása. A gyerekellátás nagyon nagy felelősség, hiszen a vizsgálatok adatain, eredményein túl, az egyéni, szubjektív tényezők figyelembevétele is elengedhetetlen. Egy csecsemő életkoránál fogva nem képes még arra, hogy pontos visszajelzést adjon a környezetének a hallókészülékes hangélményeiről. Éppen ezért a hallókészülék optimális müködésének megítéléséhez a szakembereknek kell „megtanulniuk olvasni" az egyéb jelekből, mint pl. a kisgyerek viselkedésének megváltozása, az eddig kialakult napirend „felborulása”, hangulatváltozások, hiszen ezek háttér információként sokat elárulhatnak a hallókészülék-illesztés sikerességéről.

A hallókészülék kiválasztásának folyamatában (mely kisgyermekek esetében a többféle hallókészülék kipróbálása miatt akár néhány hónap is lehet) az optimális illesztés elérésének szempontja mellett további cél az is, hogy ne csak meghallja a hangokat, hanem az erősítés mértéke tegye lehetővé a beszédértést is. Abban az esetben, ha a hallásveszteség mértékének következtében ez néhány hónap elteltével sem lehetséges, felmerül a cochleáris implantáció szükségessége. 


\title{
Fővárosi Pedagógiai Szakszolgálat Hallásvizsgáló, Gyógypedagógiai Tanácsadó, Korai Fejlesztő, Oktató és Gondozó Tagintézménye
}

2013 óta a Hallásvizsgáló Országos Szakértői és Rehabilitációs Bizottság a Fővárosi Pedagógiai Szakszolgálat Hallásvizsgáló, Gyógypedagógiai Tanácsadó, Korai Fejlesztő, Oktató és Gondozó egyik tagintézményeként müködik tovább. (15/2013 (II.26) EMMI rendelet) Az előző évek gyakorlatának megfelelően továbbra is feladata a szakértői bizottsági tevékenység, országos ellátási körzettel. A korai fejlesztéshez vezető útnak egy újabb fontos állomása, mivel szakértői vélemény és kiállított javaslat alapján vehető csak ingyenesen igénybe a korai fejlesztés mint szolgáltatás. Az érvényben lévő jogszabály alapján a 18 hónaposnál fiatalabb kisgyerekek esetében a bizottság személyes megjelenés nélkül is kiállítja a korai fejlesztésre való jogosultságot, de ehhez szükség van a szülő írásban benyújtott kérésére és a hallássérülést igazoló előzetes orvosi/gyermekneurológiai vizsgálatok eredményeire. 18 hónapos kor felett a szakértői bizottság elvégzi az életkor-specifikus pedagógiai és pszichológiai vizsgálatokat, majd javaslatot tesz a gyermek lakóhelyéhez közel eső korai fejlesztést végző intézményre. A 0-3 éves korú kisgyerekeknek hetenként min. 1, max. 4 óra vehető igénybe (Hatályos Jogszabályok Gyüjteménye, 2013).

A napi gyakorlat azt mutatja, hogy az audiológiai állomások gyógypedagógusok hiányában nem tájékoztatják a szülőket a szakértői bizottságok müködéséről, feladatköréről. Így sajnos a családok sokszor „elkallódnak”, és hónapokat is veszíthet egy kisgyerek, mire a szülö kideríti, hogy hogyan is férhet hozzá ingyenesen a korai fejlesztéshez.

\section{A korai fejlesztés, korai intervenció jelentősége}

A korai fejlesztés hatékonysága evidencia alapú a gyógypedagógia minden területén. A korai beavatkozás intenzív és kedvező folyamatokat indít el, újabb szinapszis kapcsolatok alakulnak ki, egyes hátrányok idővel felszámolhatók.

A hallássérült kisgyerekek esetén különösen fontos, hogy minél elöbb elkezdődjön a terápiás beavatkozás, mivel a hallópálya érése nem fejeződik be közvetlenül a születést követően, hanem $\mathrm{kb}$. a negyedik életévig, részben külső ingerek hatására alakítható. Az agyi plaszticitás mellett további érv még az első életévek szenzitív időszakának kihasználása is.

A korai hallásfejlődés elősegíti a korai kommunikációs készségek alakulását, kapcsolódva a korai társalgáshoz, interakcióhoz és azokhoz a területekhez, melyek elengedhetetlenek a nyelvfejlődés és a kognitív fejlődés szempontjából (Archbold, 2010).

\begin{abstract}
„A korai fejlesztés, korai tanácsadás fogalmát külföldön és hazánkban egyaránt kezdi felváltani a korai intervenció fogalma. Ez a fogalomváltás nem egyszerüen korszerübb, hangzatosabb szakmai terminológia, hanem nagyon mély tartalmi, szemléletbeli váltást is jelent az egész gyógypedagógián belül. Számos árnyalt jelentésbeli különbözőségen túl a legfontosabb üzenete számunkra a családra irányuló figyelem, és a velük történő együttmüködés hangsúlyozása".
\end{abstract}

(Baranyi-Fejes, 2012)

A koragyermekkori intervenció az eltérő fejlődésű gyermekek tervszerüen felépített programja, a család segítése, mely az egyedi igényeket is figyelembe veszi (Czeizel, 2009).

A korai intervenció célja a fejlődési elmaradás, sérülés korai életszakaszban történő felismerését követően a sérült kisgyermeket nevelő családok segítése, a gyermek sérült vagy lassabban kialakuló készségeinek fejlesztése, a jobb életminőség és a szociális kapcsolatok támogatása. 
A hallássérültek pedagógiája szakterület a korai intervenció fogalmát, szemléletét régóta alkalmazza, hiszen a terápia a szülő-gyermek-terapeuta hármasára épül, együttmüködésük nélkül a terápia elképzelhetetlen.

A korai fejlesztés területén dolgozó hallássérültek pedagógiája szakos terapeuták a jelenleg hatályban lévő jogszabály értelmében a 0-3 (4) éves korú hallássérült kisgyerekekkel és családokkal foglalkoznak. Az ellátás módja utazó vagy ambuláns formában történik, attól függően, hogy milyen igény érkezik a család részéröl. A 3. életév betöltése után azok a gyerekek, akik többségi óvodába mennek, az integrációhoz tartozó utazó tanári szolgáltatást vehetik igénybe, ami azt jelenti, hogy - kevés kivétellel - másik terapeuta lép az előző helyébe.

Hazánkban a korai fejlesztés a naturális-auditív-orális terápia alapelveire épül. A terápia a fiziológiás hallás maximális kihasználásával a természetes beszédfejlődést követi, melynek alapja a beszélő nyelvi környezet.

Mitchell és Karchmer kutatásai alapján a veleszületett hallássérüléssel született kisbabák 95 \%-a halló szülők gyermeke, az anya a sajátos kommunikációs készletét és a hangos beszédet használja gyermekével (Archbold, 2010).

Morag Clark, a naturális-auditív-orális irányzat elkötelezett híveként hangsúlyozza annak fontosságát, hogy az anya mindig az anyanyelvén adja a nyelvi mintát hallássérült gyermeke számára, mivel semmilyen tanult, második nyelven nem tudja ugyanolyan hitelesen átadni a nyelvet kiegészítő metakommunikatív, emocionális tartalmakat, mint a gyökerekböl építkező és mélyen elraktározódott anyanyelv eszköztárán keresztül. Példa erre a migráns hátterü családok esete is. A terapeutának akkor is bátorítania kell az anyákat anyanyelvük használatára, ha a hallássérült kisgyereket körülvevő társadalmi környezet nyelve ezzel nem azonos (Clark, 2007).

\section{Szülö-terapeuta együttmüködése}

A tanácsadás-irányítás szempontjainak a kezdetektől érdemben kell segíteni a szülőket, hiszen a diagnózis és az azt követő időszak nehézségei nagyon megterhelik a családokat, és az új élethelyzet számos kihívást hoz a hétköznapokban.

\section{Az „élet valóság” - a szülő szemszögéből}

Minden szülőnek természetes vágya, hogy gyermeke egészségesen szülessen, boldog életet éljen és felnőttkorára sikeresen beilleszkedjen a társadalomba.

A hallássérülés gyanújának beigazolódása a családok életében a tervezettől eltérően egy másfajta élet kezdetét is jelenti, a hétköznapok sok ismeretlen feladatot, kihívást hoznak.

A diagnózist követően, egy természetes gyászfolyamaton mennek keresztül a szülök, mely során meg kell gyászolniuk az egészségesnek hitt gyermekük elvesztését. Nagyon fontos, hogy a szakemberek türelemmel és megértéssel forduljanak a szülők felé, hiszen tele vannak bizonytalansággal, kérdésekkel. „Fog beszélni, és ha igen, mikor” „de, ugye meggyógyul”, „milyen gyógyszert kell szednie, hogy megszűnjön a hallássérülés” ehhez hasonló kérdéseket gyakran hallhatnak a szakemberek. Ebben az új, sokkoló helyzetben a szülőknek nagyon nehéz „meghallani” és elfogadni azt a tényt, hogy gyermekük hallássérülése nem gyógyítható, és bár van segítség, a hallássérülés, végleges állapot.

Minden szülőnek saját magának kell feldolgoznia az őt ért traumát karaktere, személyisége, élethelyzete alapján. Éppen ezért ez is nagyon különböző lehet.

A fiatal, súlyos fokban hallássérült kisgyerekek nem úgy reagálnak az édesanyjukra, mint a halló csecsemők. A reakciók hiányát kudarcként élheti meg az anya, 
ami odáig vezethet, hogy megváltoztatja az interakciójának jellegét, és a hallássérült gyermeke számára nem biztosítja tovább azt az ingergazdagságot, amiben a halló gyerekek részesülnek (Archbold, 2010).

Tucker-Nolen kutatópáros megfigyelte, hogy a kb. 18 hónapos korú hallássérült gyerekek édesanyjának beszéde mennyiségi és minőségi szempontból is megváltozik a halló gyerekek édesanyjának beszédéhez képest.

Kevesebbet beszélnek gyermekükkel, több felszólító és kevesebb kijelentő mondatot használnak. Egyszerübben fogalmaznak, egyszerübb nyelvi szerkezeteket alkalmaznak. Inkább szavakat, mintsem mondatokat használnak, de a mondatok rövidek, jellemzőjük az egyszerűsített nyelvhasználat. Mivel a gyermek kevesebb hangot ad, az anyai megnyilatkozások száma és minősége is csökken, és idővel nem veszi észre gyermek kommunikációs kísérleteit sem. A reakció elmaradásával hiányzik az a megerősítés, ami a hangos beszéd alapeleme lenne és feltétele a szerepcserének. Jellemző lehet az is, hogy az anya tanítani akar, ezért gyakran tesztel, visszakérdez, inkább szavakat használ és gyakoroltat, így eltorzul a gyermek nyelvi környezete. Az anya kevésbé terjeszti ki a gyermek beszédét, és gyakoribbak részéről a kritikus, negatív reakciók. Egy idő után a gyermek kevésbé lesz kezdeményező, hiszen a sok negatív hatás elveszi a kedvét, ami nemcsak a nyelvfejlődésére hat negatívan, de az anya-gyerek kapcsolatra is rossz hatással van. Előfordul az is, hogy az anya beszéde elhalkul vagy felgyorsul, és szinte csak magában beszél, így rosszul hallhatóvá válik hallássérült gyermeke számára (Tucker-Nolen, 2005).

Mivel a szülők (főleg az édesanyák) vannak a gyermekeikkel, nagyon fontos, hogy a közös idő élményekkel gazdagon és hasznosan teljen, hiszen ennek az időszaknak óriási jelentősége van a hallássérült kisgyerekek jövőjének szempontjából.

\section{A „terápiás valóság” - a terapeuta szemszögéből}

Ismerve az anyai beszéd torzulásának veszélyét, a hallássérültek pedagógiája szakos gyógypedagógusnak mindent meg kell tennie annak érdekében, hogy az anya-gyerek kommunikáció minősége és mennyisége ne változzon meg az anyákban a hallássérülés tényének ismeretében. Feladata továbbá az is, hogy segítse a szülőket (elsősorban az anyákat) abban, hogy a szeretetbeszéd nyelvén forduljanak a csecsemőjük felé, és használják ki a hétköznapok során a nyelvfejlesztés lehetőségeit.

A tanácsadás és irányítás egyaránt fontos területei a szurdopedagógus munkájának, hiszen minden egyes család egyedi, és a benne lévő családtagok is különböző egyéniséggel, személyiséggel rendelkeznek. Ezeket az egyéni sajátosságokat mindig figyelembe kell venni a fejlesztő munka során.

A hallássérült kisgyerekek megsegítése a kooperációs modell alapelveire épül. Ennek a modellnek az együttmüködés képezi az alapját, a terapeuta segítőként van jelen, tiszteletben tartva, hogy az édesanya ismeri legjobban a gyermekét (BöhlerKreitlov, 2005).

A szakmai és a szülöi kompetencia harmóniája meg kell, hogy maradjon az együttműködésben, ennek feltétele az is, hogy mindenki megmaradjon a saját szerepkörében.

A közös elfogadás, bizalom, őszinteség, türelem, alapvető tényezői a jó szülöterapeuta kapcsolatnak, mely idővel meghozza a közös munka eredményét.

A gyógypedagógus felelőssége igen nagy, hiszen tudása nem korlátozódhat kizárólag csak a terápiás foglalkozások idejére. Fel kell tudni mérnie azt is, hogy a meglévő hallókészülék a hallássérüléshez képest kellő mértékben erősít-e, szükséges-e állítani a hallókészüléken, és ezeket az észrevételeit meg kell osztania a szülőkkel is. 
A hallássérült kisgyermekek életútját meghatározó korai szűrés...

A mai technikai lehetőségek megkívánják a szakemberek ez irányú tájékozottságát, szakmai érdeklődését, nyitottságát, így ha egy súlyos fokban hallássérült kisgyerek beszédértése nem biztosított hallókészülékkel, mindenképpen felmerül a cochleáris implantáció szükségessége.

\section{Cochleáris implantáció}

A cochleáris implantátum egy olyan elektronikus eszköz, mely a külső hangforrásból érkező különböző frekvenciájú hangok akusztikus energiáját elektromos stimulusokká alakítja át, és ezt közvetlenül a hallóideg sejtjeire továbbítja (Speer és Ribari, 2002). Két részből, a beültetett belső, és egy külső egységből áll.

Veleszületett nagyothallás esetén a mütét célja minden esetben az, hogy az implantátumot viselők egy teljesebb élet várományosaként a lehető legjobb minőségben megtanuljanak beszélni, és be tudjanak illeszkedni halló társaik közé. Korai beavatkozás esetén a nyelvfejlődéshez szükséges feltételek biztosításával normál nyelvfejlődés várható.

Az elmúlt évtizedek hazai és nemzetközi tapasztalatai egyaránt igazolták a cochleáris implantáció létjogosultságát és sikerességét. A 60-as évektől kezdve mára már több százezren viselnek implantátumot a világon. Magyarországon először Budapesten, 1985-ben végezték el az első CI mütétet a SOTE Fül-Orr-Gégészeti és Fej-Nyaksebészeti Klinikán, prof. Dr. Ribári Ottó vezetésével (Küstel, Ribári és Répássy, 2002).

1995 óta Szegeden, a SZOTE Fül-Orr-Gégészeti és Fej-Nyaksebészeti Klinikán is folyamatosak a beültetések, majd évekkel később a Pécsi Tudományegyetem FülOrr-Gégészeti és Fej-Nyaksebészeti Klinika és a Debreceni Fül-Orr-Gégészeti és FejNyaksebészeti Klinika is csatlakozott a mütéti programhoz.

A mütéti beavatkozás mára már rutin mütétnek számít, és a különböző választható mủtéti technikáktól függően, másfél-két óra alatt elvégezhető.

Sajnálatos, de az eddigi tapasztalatok azt mutatják, hogy ma még hazánkban kevesen tudnak erről a lehetőségröl, így az információhiány következtében megnő azoknak a szakembereknek (gyerekorvos, védőnő, audiológus, gyógypedagógus) a felelőssége, akik a hallássérült gyermekkel és szüleikkel kapcsolatban állnak.

A 2015 szeptemberére tervezett kötelező objektív újszülöttkori szűrés következményeként várható, hogy a korai diagnosztika révén a jövőben a súlyos fokban hallássérült kisgyerekek időben hozzájuthatnak a cochleáris implantáció lehetőségéhez.

Van olyan nemzetközi vizsgálat, melynek eredményei alátámasztják, hogy a korai (1 éves kor alatti) időszakban történő cochleáris implantációt követően, a mütét után egy évvel, a videó- analízis módszerével összehasonlított halló és hallássérült csecsemők preverbális kommunikációja között nincs szignifikáns különbség (Tait, De Raeve és Nikolopoulos, 2014).

A sikeres és korai beültetés azonban önmagában nem elegendő. A tanácsadásirányítás elvei alapján megvalósuló szülő-gyógypedagógus együttműködése szintén alapvető. Mondhatjuk úgy is, hogy a cochleáris implantátum sikeres beültetése maga a hallás kapuja, de éveken át tartó szurdopedagógiai terápia szükséges ahhoz, hogy a beszédtanulás felé vezető út is járhatóvá váljon.

\section{Nehézségek az ellátórendszerben}

Egy ellátórendszer akkor működik jól, ha megvan benne a folyamatosság, egymásra épülö lépcsőfokok helyes sorrendje, különböző szakmai területek együttmüködésével, érvényesül a multidiszciplináris szemlélet. A korai fejlesztéshez vezető út során számos olyan nehézség merül fel, mely akadályozza mindennek a megvalósulását. 
Az objektív szűrés kötelező bevezetése mérföldkő az érintettek esélyegyenlősége és a hallássérültek pedagógiájának szempontjából, de csak az első alapköve a jó ellátásnak.

Lényeges, hogy a szürést követően a jövőben már nem lehet sok olyan „mulasztás”, akár a család, a környezet, akár a szakember részéről, mint korábban volt, hiszen, az első szűrés alkalmával kiszűrt gyerekek már a rizikó csoport tagjaként újabb vizsgálatra lesznek visszahívva, így szem előtt maradnak. Mindenképpen el kell érni, hogy a szürőn fennakadt gyerekekkel szüleik visszajöjjenek a második mérésre, mely még akár meg is cáfolhatja a hallássérülés tényét. $A$ tervezettek szerint a második mérés már az egyes klinikák audiológiáján lesz, így mindenképpen veszélyforrás lehet, hogy nem jelenik meg a szülő az új mérőállomáson. A külföldi tapasztalatokat figyelembe véve azzal is számolnunk kell, hogy az első néhány évben túl sok a fals pozitív eredmény. A szüréseket végző szakemberek képzése ellenére a szűrőmódszer bevezetésekor néhány év biztosan kell ahhoz, hogy a kiszürt gyerekek aránya megközelítse a lehetséges veleszületett hallássérülések számát.

További nehézséget jelenthet, hogy a csecsemők ellátására az audiológiai állomások többsége nincs felkészülve. Kevés kivétellel hiányoznak a gyógypedagógusok, akik segítői lehetnének a hallókészülék-kiválasztás és -ellátás folyamatának. A hallássérült szakirányon végzett terapeuták évekig tanulnak azokról a hallássérült kisgyerekre jellemző speciálisszükségletekröl, melyek segítségével egy másfajta szempontrendszerrel segíteni tudják a gyermek reakcióinak, kommunikációs kezdeményezéseinek, jelzéseinek értelmezését.

Az objektív módszerek a szürés értékén túlmutatnak ugyan, de nem elegendőek ahhoz, hogy önmagukban egy kisgyerekre hallókészüléket lehessen illeszteni.

A kisgyermekkori hallókészülék-ellátás nagyon nagy felelősség, melyben az objektív eredmények mellett a szubjektív módszerek eredményei, és az érintett hallássérült kisgyerek sajátos visszajelzései és érzékenységének szempontjai is egyaránt figyelmet kell, hogy kapjanak. Az életkor specifikus pedoaudiológiai módszerek kiegészítő alkalmazása ebben is nagy segítséget jelenthetne egy orvosi-audiológusigyógypedagógiai teamben.

A korai hallókészülékes ellátásban a hallókészülék jó beállításán túl szükséges annak a hangsúlyozása is, hogy a hallássérült kisgyerekek hallásához csak akkor lehet minél pontosabban elvégezni a hallókészülék-illesztést, ha a találkozások, visszajelzések, kontrollvizsgálatok időről időre megvalósulhatnak. Sajnálatos, de ez a szemlélet sok esetben a szüréstől függetlenül sem valósul meg a napi gyakorlat részeként.

A hallókészülék-ellátás folyamata mellett további nehézséget jelenthet, hogy a szülő nem kap megfelelő tájékoztatást a további lehetőségeiröl, teendőiröl. Érdemes többféle hallókészüléket is kipróbálni és gyógypedagógiai segítséggel összehasonlítani a tapasztalt különbséget. Ha a hallókészülékes fejlesztés nem eredményes, fel kell ajánlani a cochleáris implantáció lehetőségét. Erről a műtéti eljárásról, annak ellenére, hogy Magyarországon már a '90-es évek óta gyerekeknél is nagy sikerrel alkalmazzák, kevesen tudnak, vagy kellő információk hiányában maguk a szakemberek sem javasolják időben az elvégzését. Nehézség lehet az is, hogy ha a szülőnek tudomása is van arról, hogy gyermeke fejlődésének megsegítése érdekében igénybe veheti a szurdopedagógus/hallássérültek pedagógiája szakos terapeuta segítségét, ilyen szakember nincs számára elérhető távolságban, nincs a lakóhelye közelében. Amióta a korai fejlesztés mint szolgáltatás szigorú szabályozás eredményeként a szakszolgálatokon keresztül vehető igénybe, országos viszonylatban nehezítetté vált a hallássérült kisgyerekek korai fejlesztése. 
A már jól kidolgozott és jól működő napi gyakorlat hullott szét azzal, hogy a speciális iskolákhoz, egyesített módszertani intézményekhez tartozó korai fejlesztés területét nem végezhetik többé azok a jól felkészült szakemberek, akik ezekben az egyesített módszertani központokban dolgoznak. Bár a Korai fejlesztő és Módszertani Központok továbbra is fogadhatják helyhez kötötten a hallássérült kisgyerekeket, számuk elenyésző, és csak kevés gyermek számára hoznak megoldást. A jelen helyzet országos szinten azt mutatja, hogy a szakszolgálatok többsége szakemberhiánnyal küzd, és nehezen biztosítja a hallássérültek pedagógia szakos, naprakész tudású gyógypedagógust. Annak ellenére, hogy az lenne a cél, hogy a szülö-gyermek-terapeuta hármasán keresztül a kooperációs modell valósuljon meg, még gyakran előfordul, hogy a szülő kívülálló marad, a foglalkozásokon nem vehet részt, csak utólag értesül „az anyagról" házi feladat formájában. Ez a régi, elavult gyakorlat, a gyermekcentrikus modellre épülve, merőben ellenkezik a ma kívánatos szemlélettel. Egy másik, szintén a gyakorlattól távoli modell a ko-terapeuta modell, ami szintén kerülendő. Bár a szülő ebben a modellben aktívan részt vesz a foglalkozásokon, szülői szerepköréböl kilépve szinte segédterapeuta válik belőle. Ennek hosszú távú hatása kedvezőtlenül érinti a szülögyerek kapcsolatot, hiszen otthon is mindig egy terapeuta lesz a gyermekkel. Gyakori nehézség az is, hogy mire sikerül „találni” szakembert, a segítségre váró család és kisgyerek értékes időt veszít, és nem egyszer a 3. életév betöltésével óvodakötelessé válik a kisgyerek, így még csak be sem kerül a korai fejlesztés ellátórendszerébe. Ennek a rendszernek a hiányosságai - elsősorban a minőségi ellátás - egyre nagyobb gondot okoz vidéken, azon belül is föleg a kisebb településeken élők helyzete nehezített, vagy kilátástalan.

\section{Összegzés}

A korai fejlesztés és intervenció ellátórendszerének hiányosságait látva a hallássérültek pedagógiája területén is akad még bőven tennivaló. Míg a fővárosban viszonylag rövidebb és gördülékenyebb út vezet a korai fejlesztéshez, addig vidéken számos nehézséggel kell szembenézniük a családoknak. Az ország egyes régióiban az ellátás feltételei különböző mértékben adottak és számos akadályba ütköznek, mindez megnehezíti a hallássérültek pedagógiája szakos gyógypedagógusokkal való kapcsolatfelvételt, közös munkát.

Az objektív hallásszürés kötelező jellegének bevezetése hosszútávon is döntő jelentőségű a veleszületett hallássérült kisgyerekek életútja szempontjából. A korai diagnózis jó prognózist adhat ahhoz, hogy az időben felfedezett hallássérült kisgyerekek mielőbb megkapják a hallókészüléket vagy a cochleáris implantátumot, esélyt kapva a sikeres integrációra, társadalmi esélyegyenlőség megvalósulására. Éppen ezért a szakembereknek is az interdiszciplináris teammunkát szem előtt tartva együttesen kell összefogniuk annak érdekében, hogy a XXI. század technikai vívmányai találkozhassanak a hatékony, minőségi ellátással.

\section{Irodalom}

Archbold, S. (2010): Pediatric cochlear implantation: establishing the intervention and its context. In: Deaf Education Changed by Cochlear Implantation? 17-51.

Baranyi Ildikó és Fejes Gabriella (2012): Hallássérült kisgyermekek korai fejlesztése In: Perlusz Andrea (szerk.) ,...Aki olvassa, értse meg...” Csányi Yvonne köszöntése. ELTE BGGYK, Budapest, 64-83. 
Beke Zsolt, dr. (2009): Univerzális neonatális hallásszürés-módszerek, feladatok a védőnők szemszögéből. (Előadás, Bajai Kórház, Fül-Orr-Gégeosztály)

Beke Zsolt, Katona Gábor, Pytel József, Szabó Zsolt, Tamás László és Zsilinszky Zsuzsanna (2009): Szakmai irányelv a 0-18 éves gyermekek teljes körü, életkorhoz kötött hallásszüréséröl. Mediton Kiadó, Budapest.

Böhler-Kreitlow, Dagmar (2005): A szülök és szakemberek együttmüködése. In: dr. Csányi Yvonne (szerk.): A hallássérült gyermekek korai fejlesztése, ELTE Bárczi Gusztáv Gyógypedagógiai Föiskolai Kar, Budapest, 83-96.

Clark, M. (2007): Parent Guidance. In: Clak, M. A Practical Guide to Quality Interaction with Children who Have a Hearing Loss. Plural Publishing, Inc., Abingdon Oxfordshire, 49-61.

Czeizel Barbara (2009): A koragyermekkori intervenció múltja, jelene és remélt jövője. Gyógypedagógiai Szemle, 37. 2-3. 153-160.

Hatályos Jogszabályok Gyüjteménye 15/2013. (II. 26.) EMMI rendelet a pedagógiai szakszolgálati intézmények müködéséről /3. A gyógypedagógiai tanácsadás, korai fejlesztés, oktatás és gondozás/

Kereki Judit (2013): A koragyermekkori intervenciós rendszer működésének legfontosabb problématerületei és fejlesztési lehetőségei. Gyógypedagógiai Szemle, 61. (1.) 23-38.

Keresztessy Éva (2012): A hallássérülés felfedezése, diagnosztizálása és ellátásának folyamata ahogyan történnie kellene - és ahogyan valójában történik. In: Perlusz Andrea (szerk.) „,...Aki olvassa, értse meg...” Csányi Yvonne köszöntése. ELTE BGGYK, Budapest, 49-63.

Küstel Marianna, Ribári Ottó és Répássy Gábor (2002): A süketség gyógyításának hazai eredményei és perspektívái: a cochleáris implantáció. LAM (Lege Artis Medicinae), 12. (4), 235-239.

Magyar Közlöny 2015. évi 42. szám 6. melléklet a 16/2015. (III.30.) Emmi rendelethez online letöltés www.kozlonyok.hu

Marschark, M. és Spencer, P. E. (2009): Evidence of best practice models and outcomes in the education of deaf and hard-of-hearing children: an international review. National Council for Special Education.

Ranschburg Jenő (2007): Az anya és a magzat kapcsolata. In: Ranschburg Jenő Szülök könyve, Saxum Kiadó Bt., Budapest, 35-42.

Speer Józsefné és Ribári Ottó (2002): A cochleáris implantáció 15 év szakmai tapasztalatai alapján. In: Dr. Csányi Yvonne (szerk.) Cochleáris implantáción átesett gyermekek terápiája és fejlődése. Egy Soros projekt két éves munkájának eredményei. ELTE Bárczi Gusztáv Gyógypedagógiai Főiskolai Kar, Budapest, 15-23.

Tait M., De Raeve L. és Nikolopoulos T. (2014): Early communication skills (Deaf children with cochlear implants before the age of one year: comparison of preverbal communication with normal hearing children) In: Leo De Rave (ed.) Paediatric Cochlear Implantation: outcomes and current trends in education and rehabilitation. UB Nijmegen, 110-120.

Tucker I., Nolan, M. (2005): A hallássérült gyermek nyelvi fejlesztése. In: Dr. Csányi Yvonne (szerk.): A hallássérült gyermekek korai fejlesztése. ELTE Bárczi Gusztáv Gyógypedagógiai Főiskolai Kar, Budapest,127-146.

Werker, J. F., Jeung H. H. és Yoshida, K. A. (2012): How Do Infants Become Experts at Native-Speech Perception? Association for Psychological Science Current Directions is Psychological Science, 21. (4). 221-226. 